\title{
Genotoxic and Mutagenic Effects of Melissa officinalis (Erva Cidreira) Extracts
}

\author{
A. M. Alves ${ }^{1}$, L. S. Vidal ${ }^{1}$, R. M. Kuster ${ }^{2}$, C. Lage ${ }^{1}$, and A. C. Leitão ${ }^{*}, 1$ \\ ${ }^{1}$ Laboratório de Radiobiologia Molecular, Programa de Biologia Molecular e Estrutural, Instituto de Biofísica Carlos \\ Chagas Filho, UFRJ; ${ }^{2}$ Núcleo de Pesquisas de Produtos Naturais - UFRJ, Brazil
}

\begin{abstract}
Erva cidreira (Melissa officinalis) is a plant with sedative properties and in Brazil it has been used for insomnia and anxiety. It is also employed to stimulate liver functions and normalize menstruation and for intestinal constipation. The aim of this work was to evaluate the genotoxic and mutagenic effects of erva cidreira. Results indicate the presence of genotoxic activity in the lyophilized extract, with lysogenic induction increasing about 80 -fold over the spontaneous background after treatment with lyophilized total aqueous extract. Beta-galactosidase levels raised 9-fold in indicator strains after treatment under the same conditions. A deeper look into the mechanism underlying the genotoxic action implicated reactive oxygen species generated by compounds retained in the ethyl-acetate, polar partition of the total aqueous extract. The spectrum of mutations revealed a great trend for base substitutions, mainly in guanines and adenines. The presence of phenolic compounds, especially caffeic acid derivatives, may be correlated to its genotoxic activity. We thus conclude that compounds present in current concentrations of erva cidreira extracts are genotoxic and mutagenic, and might have carcinogenic potential.
\end{abstract}

Keywords: Melissa officinalis, genotoxicity, reactive oxygen species, mutagenesis, caffeic acid.

\section{INTRODUCTION}

Melissa officinalis is a bush plant from the Lamiaceae family, known in Brazil as erva cidreira. Erva cidreira has many uses in ethno medicine. Infusions prepared from stem and leaves are used as tranquilizer for insomnia and anxiety. Its essential oil is indicated to normalize menstrual irregularities, to eliminate digestive gases and to counteract constipation. Besides, it has been used against viral infections such as influenza, herpes, mumps and smallpox (Dimitrova Acta Microbiol Bulg 1993) [1] (Koytchev Phytomedicine 1999) [2] (Mikus Planta Med 2000) [3]. Yamasaki et al. (Biol Pharm Bull 1998) [4] have experimentally observed the antiviral and cytostatic actions against the Human Immunodeficiency Virus due the inhibition of its reverse transcriptase in vitro. A beneficial action on treatment of Alzheimer disease has also been reported (Perry J Pharmacol 1999) [5].

The use of medicinal plants is an old practice in human populations; however there are still lacking controlled studies on these plants and the risks of their consumption are unknown. Moreover, plant material of non-certificated origin is often contaminated by toxic substances, and behind the standards of microbial quality control. Studies on the biological effects of medicinal plant extracts are thus complicated because they comprise a chemical mixture of several substances (Sugimura Cancer Res 1983) [6]. The uncontrolled use of these extracts by general population claim for studies on their side effects and toxicity.

*Address correspondence to this author at the Instituto de Biofísica Carlos Chagas Filho, Av. Carlos Chagas Filho, 373, CCS Bloco G - Cidade Universitária, CEP - 21941-902, Rio de Janeiro - Brazil; Tel: +55-21-25626578; Fax:+55-21-2280-8193; E-mail: acleitao@biof.ufrj.br
The absence of basic information on genotoxic effects associated to the use of Melissa officinallis has led us to use different assays to evaluate its genotoxic and mutagenic activities. Genotoxic activity of erva cidreira extract was evaluated by phage-induction assay - Inductest (Moreau PNAS 1976) [7] and SOS chromotest (Quillardet Mutat Res 1985) [8], while mutagenic activity was evaluated by different mutagenesis assays. The erva cidreira extract was shown to be genotoxic and mutagenic, probably due to the action of caffeic acid derivatives present in its composition.

\section{MATERIAL AND METHODS}

\section{Bacterial Strains}

The Escherichia coli and Salmonella typhimurium strains used in this work are listed in Tables $\mathbf{1}$ and $\mathbf{2}$, respectively.

\section{Bacterial Media}

Bacterial cells were grown overnight in a shaking incubator at $37^{\circ} \mathrm{C}$ in LB medium (Miller Cold Spring Harbor Lab Press 1992) [9]. A starting inoculum was taken from this culture and cells were grown under the same conditions until the culture reached the exponential phase.

The E. coli bacterial survival and infective center production assays were done using LB medium and LB medium containing $20 \mu \mathrm{g} / \mathrm{ml}$ (micrograms per $\mathrm{ml}$ ) ampicillin (LBamp), respectively. Both media were solidified with $1.5 \%$ Difco bacto agar. E medium (Vogel J Biol Chem 1956) [10] solidified with $1.5 \%$ Difco bacto agar was supplemented with histidine for the Ames test (Maron Mutat Res 1983) [11] or tryptophan for the WP2 mutagenicity test (Blanco Mutat Res 1998) [12] assays. A selective minimal medium 
Table 1. Escherichia coli Strains

\begin{tabular}{|c|c|c|}
\hline Designations & Relevant Genotype & Reference \\
\hline WP2s & WP2 $u v r \mathrm{~A} / \mathrm{pKM} 101 a m p^{\mathrm{R}}$ & Blanco et al., 1998 \\
\hline IC203 & $\mathrm{WP} 2 \operatorname{oxy\mathrm {R}} / \mathrm{pKM} 101 a m p^{\mathrm{R}}$ & Blanco et al., 1998 \\
\hline IC204 & $\mathrm{WP} 2 \Delta(u m u \mathrm{DC}) c a t^{\mathrm{R}}$ & Blanco et al., 1998 \\
\hline IC206 & $\mathrm{WP} 2 \Delta(u m u \mathrm{DC}) m u t \mathrm{Y} c a t^{\mathrm{R}}$ & Blanco et al., 1998 \\
\hline IC208 & $\mathrm{WP} 2 \Delta(u m u \mathrm{DC}) m u t \mathrm{Y}$ oxy $\mathrm{R} c a t^{\mathrm{R}}$ & Blanco et al., 1998 \\
\hline $\mathrm{CC} 101$ & $\mathrm{P} 90 \mathrm{C}$ ara $\Delta(\text { lac proB })_{\mathrm{XIII}}(\mathrm{A}: \mathrm{T} \Rightarrow \mathrm{C}: \mathrm{G})$ & Cupples and Miller, 1989 \\
\hline $\mathrm{CC} 102$ & $\mathrm{P} 90 \mathrm{C}$ ara $\Delta(\text { lac proB })_{\mathrm{XIII}}(\mathrm{G}: \mathrm{C} \Rightarrow \mathrm{A}: \mathrm{T})$ & Cupples and Miller, 1989 \\
\hline $\mathrm{CC} 103$ & $\mathrm{P} 90 \mathrm{C}$ ara $\Delta(\text { lac proB })_{\mathrm{XIII}}(\mathrm{G}: \mathrm{C} \Rightarrow \mathrm{C}: \mathrm{G})$ & Cupples and Miller, 1989 \\
\hline $\mathrm{CC} 104$ & $\mathrm{P} 90 \mathrm{C}$ ara $\Delta(\text { lac proB })_{\mathrm{XIII}}(\mathrm{G}: \mathrm{C} \Rightarrow \mathrm{T}: \mathrm{A})$ & Cupples and Miller, 1989 \\
\hline $\mathrm{CC} 105$ & $\mathrm{P} 90 \mathrm{C} \operatorname{ara} \Delta(\text { lac proB })_{\mathrm{XIII}}(\mathrm{A}: \mathrm{T} \Rightarrow \mathrm{T}: \mathrm{A})$ & Cupples and Miller, 1989 \\
\hline $\mathrm{CC} 106$ & $\mathrm{P} 90 \mathrm{C}$ ara $\Delta(\text { lac proB })_{\mathrm{XIII}}(\mathrm{A}: \mathrm{T} \Rightarrow \mathrm{G}: \mathrm{C})$ & Cupples and Miller, 1989 \\
\hline $\mathrm{CC} 107$ & $\mathrm{P} 90 \mathrm{C}$ ara $\Delta(\text { lac proB })_{\mathrm{XIII}}(+1 \mathrm{G})$ & Cupples et al., 1990 \\
\hline $\mathrm{CC} 108$ & $\mathrm{P} 90 \mathrm{C}$ ara $\Delta(\text { lac proB })_{\mathrm{XIII}}(-1 \mathrm{G})$ & Cupples et al., 1990 \\
\hline $\mathrm{CC} 109$ & $\mathrm{P} 90 \mathrm{C}$ ara $\Delta(\text { lac proB })_{\mathrm{XIII}}(-2(\mathrm{CG}))$ & Cupples et al., 1990 \\
\hline $\mathrm{CC} 110$ & $\mathrm{P} 90 \mathrm{C}$ ara $\Delta(\text { lac proB })_{\mathrm{XIII}}(+1 \mathrm{~A})$ & Cupples et al., 1990 \\
\hline $\mathrm{CC} 111$ & $\mathrm{P} 90 \mathrm{C}$ ara $\Delta(\text { lac proB })_{\mathrm{XIII}}(-1 \mathrm{~A})$ & Cupples et al., 1990 \\
\hline $\mathrm{WP} 2 \mathrm{~s}(\lambda)$ & $\mathrm{WP} 2 u v r \mathrm{~A}(\lambda) \operatorname{trp\mathrm {E}}$ & Our laboratory stock \\
\hline RJF013 & {$[\mathrm{B} / \mathrm{r} \mathrm{SR} 714] u v r \mathrm{D} 3 \operatorname{trp} \mathrm{E} a m p^{\mathrm{R}}$} & Our laboratory stock \\
\hline PQ37 & $u v r \mathrm{~A} r f a$ sfi $\mathrm{A}:: l a c \mathrm{Z}$ & Quillardet and Hofnung (1985) \\
\hline
\end{tabular}

Table 2. Salmonella typhimurium Bacterial Strains

\begin{tabular}{|c|c|c|}
\hline Designations & Relevant Genotype & Reference \\
\hline TA97 & hisD6610/ hisO1242 - $\Delta u v r \mathrm{~B} r f a \mathrm{pKM} 101\left(a m p^{\mathrm{R}}\right)$ & Maron and Ames, 1983 \\
\hline TA98 & $h i s \mathrm{D} 3052-\Delta u v r \mathrm{~B} r f a \mathrm{pKM} 101\left(a m p^{\mathrm{R}}\right)$ & Maron and Ames, 1983 \\
\hline TA100 & $h i s \mathrm{G} 46-\Delta u v r \mathrm{~B} r f a \mathrm{pKM} 101\left(a m p^{\mathrm{R}}\right)$ & Maron and Ames, 1983 \\
\hline TA102 & his 4428 - wild type $r f a \mathrm{pKM} 101\left(a m p^{\mathrm{R}}\right) \mathrm{pAQ} 1\left(\right.$ tet $\left.^{\mathrm{R}}\right)$ & Maron and Ames, 1983 \\
\hline
\end{tabular}

containing $0.4 \%$ lactose was used for the $l a c^{+}$-revertant mutagenesis assay (Cupples PNAS 1989) [13] (Cupples Genetics 1990 [14].

\section{Preparation of Melissa officinalis Extracts}

Preparation of extracts followed the same standard procedure employed by the pharmaceutical industry to obtain the phytomedicine for commercial use.

Dried leaves of certified Melissa officinalis plants were kindly provided by a local pharmaceutical industry (Laboratório Simões Ltd., Rio de Janeiro, Brazil), and they were boiled in bidistilled water $(200 \mathrm{mg} / \mathrm{ml})$ for $10 \mathrm{~min}$. The resulting infusion was filtered, lyophilized, and stored at $-20^{\circ} \mathrm{C}$ until further use. In the process of lyophilization we could retain about $11 \%$ of the original material.

\section{HPLC}

The water-reconstituted extract was analyzed by HPLC to determine its qualitative chemical composition. Ten-ml samples were injected in HPLC/DAC equipment (Shima$\mathrm{dzu})$. The stationary phase used was an RP-18 silica gel column $(10 \mathrm{~mm})$ from Merck and the mobile phase was composed by a system of solvents consisting of $\mathrm{H}_{2} \mathrm{O}+1 \%$ $\mathrm{H}_{3} \mathrm{PO}_{4}$ (solvent A), and 30\% Methanol (solvent B) for $10 \mathrm{~min}, 40 \% \mathrm{~B}$ for $20 \mathrm{~min}, 100 \% \mathrm{~B}$ for $60 \mathrm{~min}$. The flux of mobile phase was $1 \mathrm{ml} / \mathrm{min}$, and the chromatogram records were obtained by absorption at $254 \mathrm{~nm}$.

\section{Partition and Chromatography of the Reconstituted Ex- tract}

The water-reconstituted extract was successively partitioned by an extraction method using organic solvents of inc- 
reasing polarity (hexane, chloroform, ethyl acetate and butanol). Later, partitions were screened for activity by the Inductest protocol to search for fractions with genotoxic activity.

\section{CHEMICALS}

Catalase (Sigma Chemical Company - EUA) and thiourea (Indústrias Químicas Merck S/A - Brazil) were dissolved in bidistilled water. Dipyridyl (Sigma Chemical Company - EUA) was dissolved in $10 \%$ ethanol and then diluted in bidistilled water.

\section{GENOTOXIC STUDIES}

\section{Lysogenic Induction Assay}

The strains WP2s $(\lambda)$ and RJF013 of $E$. coli B/r (Table 1) were used in the lysogenic induction assay, and the protocol was similar to the quantitative Inductest developed by Moreau et al. in 1976 (PNAS) [7]. Lyophilized extracts were reconstituted and mixed to the melted medium at the amounts indicated in the $\mathrm{X}$-axis of the induction graphs. Each experimental determination was performed in duplicate, and results represent the average of at least three independent experiments. The level of induction was expressed as the induction factor, which is the ratio between the numbers of infective centers after treatment by those occurring spontaneously.

\section{SOS Chromotest Assay}

E. coli K-12 PQ37 strain (Table 1) was used in the SOS chromotest studies, according to the protocol developed by Quillardet and Hofnung (Mutat Res 1985) [8]. Results represent the average of at least three experiments. The expression of $\beta$-galactosidase is shown as enzymatic units (ordinates, obtained by measurement of absorbance at $420 \mathrm{~nm}$ immediately after each treatment) as a function of the amount of extract (abscissas).

\section{Mechanism of Action Underlying the Genotoxic Activity}

The mechanism of action by which the extract may exert its genotoxic activity was investigated by experiments in which the lysogenic induction was measured after exposure to a defined amount of erva cidreira extract (150mg/plate) in the absence (control) or in the presence of anti-oxidant compounds. As many plant extracts are capable of generate damaging reactive oxygen species (ROS), this effect was determined for the erva cidreira extract by the addition (or not) of increasing concentrations of: (a) catalase, (b) thiourea or (c) dipyridyl. Each experimental determination was performed in duplicate, and results represent the average of at least three independent experiments.

\section{MUTAGENIC STUDIES}

\section{Ames Test}

This assay was carried out as described by Maron and Ames (Mutat Res 1983) [11], using the histidine auxotroph strains TA97, TA98, TA100 and TA102 of S. typhimurium. Each experimental determination was performed in duplicate and results represent the average of at least three experi- ments. Mutagenesis induced by erva cidreira in each strain was expressed as the absolute number of $\mathrm{His}^{+}$revertants per plate (Ames Prog Clin Biol Res 1986) [15].

\section{Tryptophan Mutagenesis Assay}

This assay was carried out as described by Blanco et al. (Mutat Res 1998) [12], using the tryptophan auxotroph strains WP2s, IC203, IC204, IC206 e IC208 of E. coli (Table 1). Each experimental determination was performed in duplicate, and results represent the average of at least three independent experiments. Mutagenesis induced by erva cidreira extract in each strain was expressed as mutants per $10^{8}$ cells. The increment factor was obtained by dividing the number of induced mutants by that of the spontaneous revertants.

\section{Lactose Mutagenesis Assay}

This assay was carried out as described by Cupples and Miller (PNAS 1989) [13] and Cupples et al. (Genetics 1990) [14] using different strains constructed to detect specific base pair substitutions and frameshift mutations in the E. coli lacZ locus. Mutagenic activity was expressed as the number of revertants per $10^{8}$ cells. The increment factor was obtained by dividing the number of induced mutants by that of the spontaneous revertants.

\section{RESULTS}

\section{Genotoxicity of Erva Cidreira}

Phage induction produced by different amounts of erva cidreira extract is shown in Fig. (1). Maximal rates of phage induction were observed at $150 \mathrm{mg} /$ plate (corresponding to about 80 -fold increase over the spontaneous background).

Positive SOS induction was detected for the $u v r \mathrm{~A}-$ deficient strain PQ37 treated with different concentrations of erva cidreira extract. Results indicate the presence of genotoxic activity in the lyophilized extract, and induction of enzymatic activity reached 24 units ( $\sim 9$-fold increment over the spontaneous induction, as shown in Fig. (2) at the maximum amount used $(150 \mathrm{mg} / \mathrm{ml})$. These results strengthen those obtained with the Inductest, suggesting that the extract bears on bacterial genotoxicity.

\section{Suppression of the Genotoxicity of Erva Cidreira by Anti- oxidant Agents}

Specific antioxidant agents were used simultaneously with the extract to evaluate if the lysogenic induction observed in Fig. (1) would be due to the production of ROS. Increasing concentrations of the different antioxidant agents were added to the Indutest experiments performed with extracts at the amount of $150 \mathrm{mg} /$ plate. Catalase, dypiridyl and thiourea were shown to exert an inhibitory action on the genotoxic effect induced by erva cidreira extract (Fig. 3). Thus ROS may intermediate the genotoxic activity of this extract.

\section{Genotoxicity of Fractionated Erva Cidreira Extracts}

The aqueous fraction of erva cidreira extract was able to induce the prophage in $E$. coli WP2s( $\lambda$ ) Fig. (4) HPLC/UV 


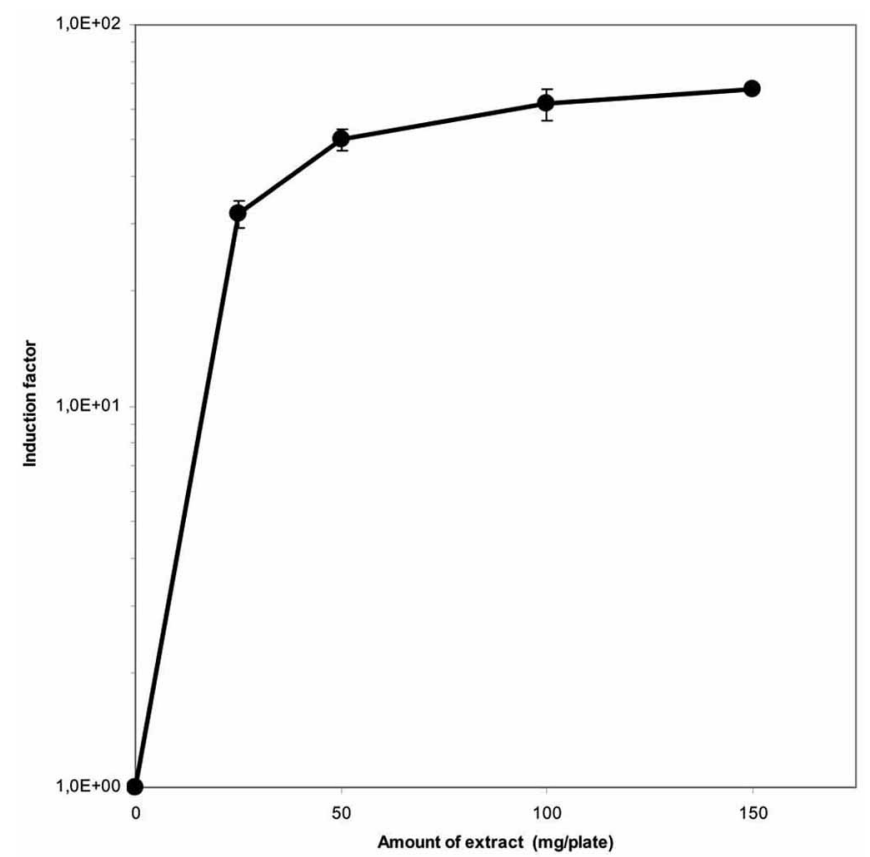

Fig. (1). Dose-response curve for prophage induction by lyophilized extracts of erva cidreira. Cultures of $E$. coli WP2s $(\lambda)$ in the exponential phase of growth were diluted $\left(10^{-4}\right)$ and samples of $0.1 \mathrm{ml}$ were pre-incubated (or not, controls) at $37^{\circ} \mathrm{C}$ for 20 min with the indicated amounts of lyophilized extract. Then, the mixtures were poured with $0.3 \mathrm{ml}$ of indicator strain (RJF013) and $3 \mathrm{ml}$ of molten soft agar onto LB-amp plates.

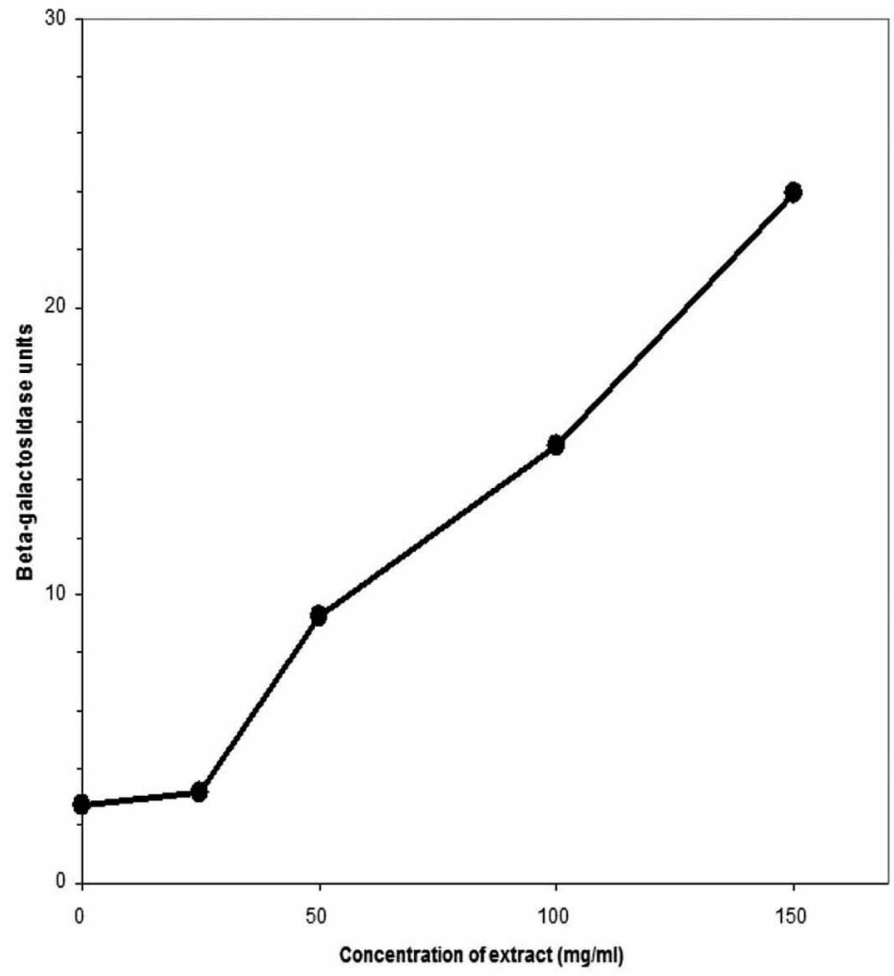

Fig. (2). Induction of $\beta$-galactosidase in PQ37 strain after treatment with different concentrations of lyophilized extract of Erva Cidreira. The induction of $\beta$-galactosidase units was calculated by means of the relation defined by Quillardet and Hofnung (1985) [11] after measurement of absorbance at $420 \mathrm{~nm}$.

analysis of this fraction indicates the presence of phenolic compounds, like benzoic acid derivatives and caffeic acid derivatives as the major components in the extract (Fig. 8). Those compounds may be thus implicated in the observed genotoxic activity present in the erva cidreira extract. Be- sides the aqueous total extract, significant prophage induction was shown to occur after treatment with the ethylacetate fraction, although reduced by a 10 -fold factor (Fig. 4). The other non-polar fractions were not effective in inducing the prophage (data not shown). 

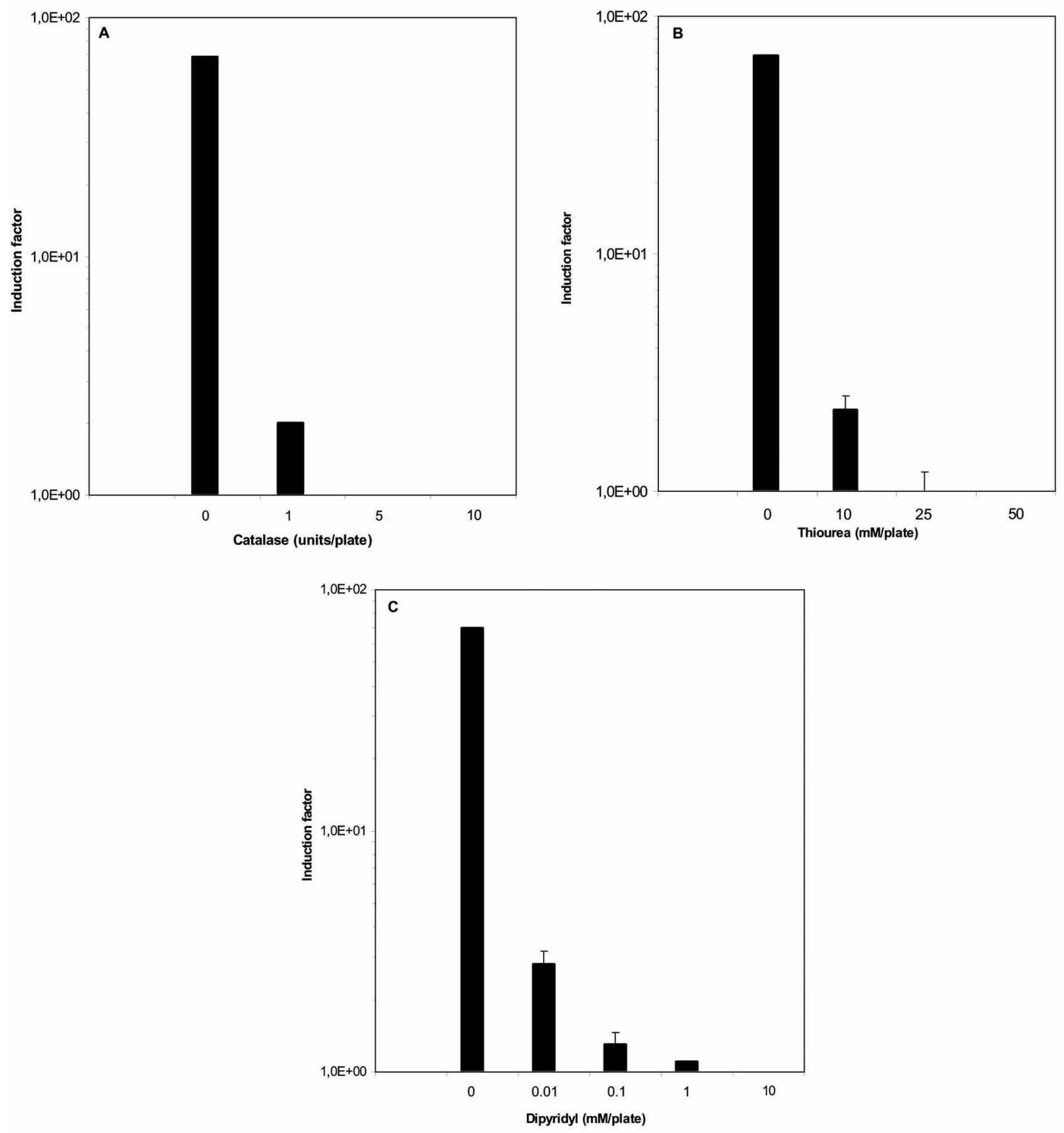

Fig. (3). Effect of (A) catalase, (B) thiourea and (C) dipyridyl on the phage-inducing activity of lyophilized extract. Cultures of E. coli WP2s $(\lambda)$ in the exponential phase of growth were diluted $\left(10^{-4}\right)$ and samples of $0.1 \mathrm{ml}$ were incubated (or not, controls) with lyophilized extract of erva cidreira $\left(150 \mathrm{mg} /\right.$ plate), and different amounts of catalase, thiourea or dipyridyl for $20 \mathrm{~min}$ at $37^{\circ} \mathrm{C}$. The mixtures were then poured on to LB-amp plates together with $3 \mathrm{ml}$ of indicator strain RJF013. The bars represent the standard errors.

\section{Primary Detection of the DNA Targets by Means of the} Ames Strains

Mutagenic effects of Erva cidreira extract was then evaluated by means of the bacterial $\mathrm{His}^{+}$reversion mutation assay (Ames test) using $S$. typhimurium strains. Except for the TA98 strain exposed to $150 \mathrm{mg} /$ plate of the extract, $\mathrm{His}^{+}$ revertants were not significantly induced in the other tested strains. Important to mention that this amount of extract was not able to cause any significant loss of viability (data not shown). This result suggests that GC sites appear to be targeted by mutagenic compounds present in the extract (Fig. 5). 


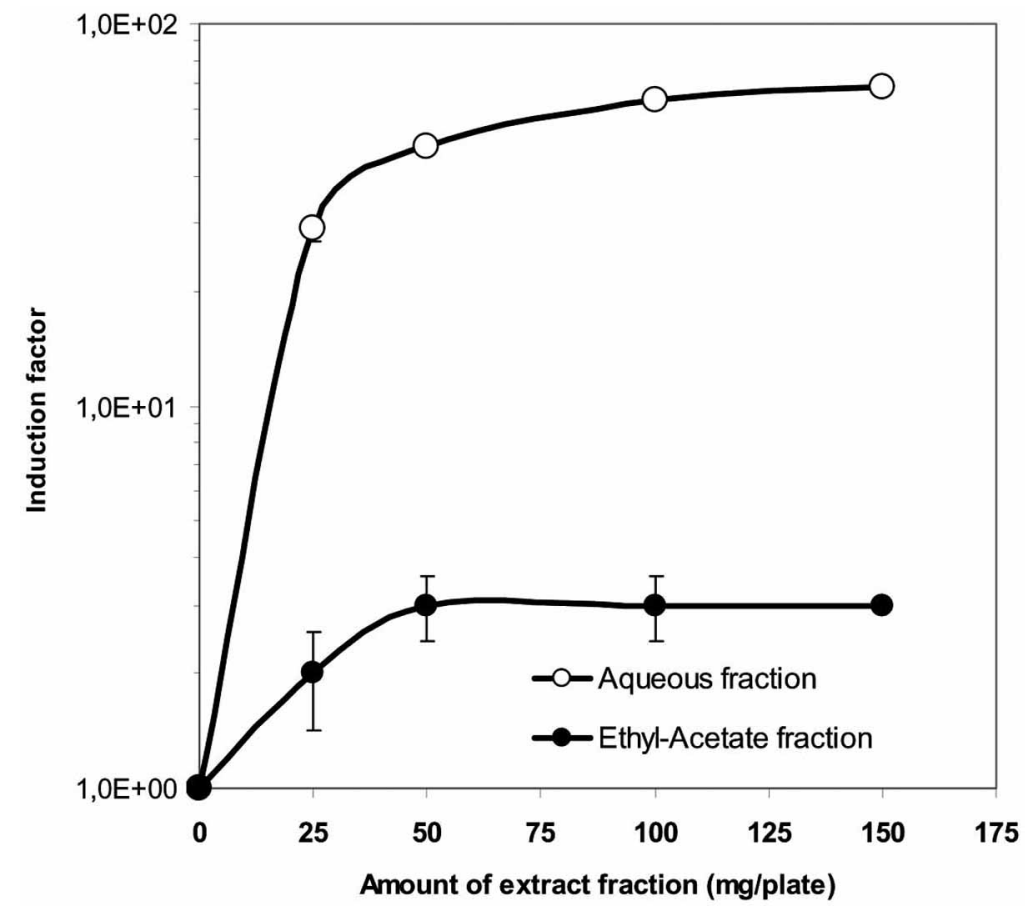

Fig. (4). Dose-response curve for prophage induction by fractioned erva cidreira extract. Cultures of E. coli WP2s( $\lambda$ ) in the exponential phase of growth were diluted $\left(10^{-4}\right)$ and samples of $0.1 \mathrm{ml}$ were incubated (or not, controls) for 20 min at $37^{\circ} \mathrm{C}$ with several amounts of the fractions. Then, the mixtures were poured with $0.3 \mathrm{ml}$ of indicator strain (RJF013) and $3 \mathrm{ml}$ of molten soft agar onto LB-amp plates.

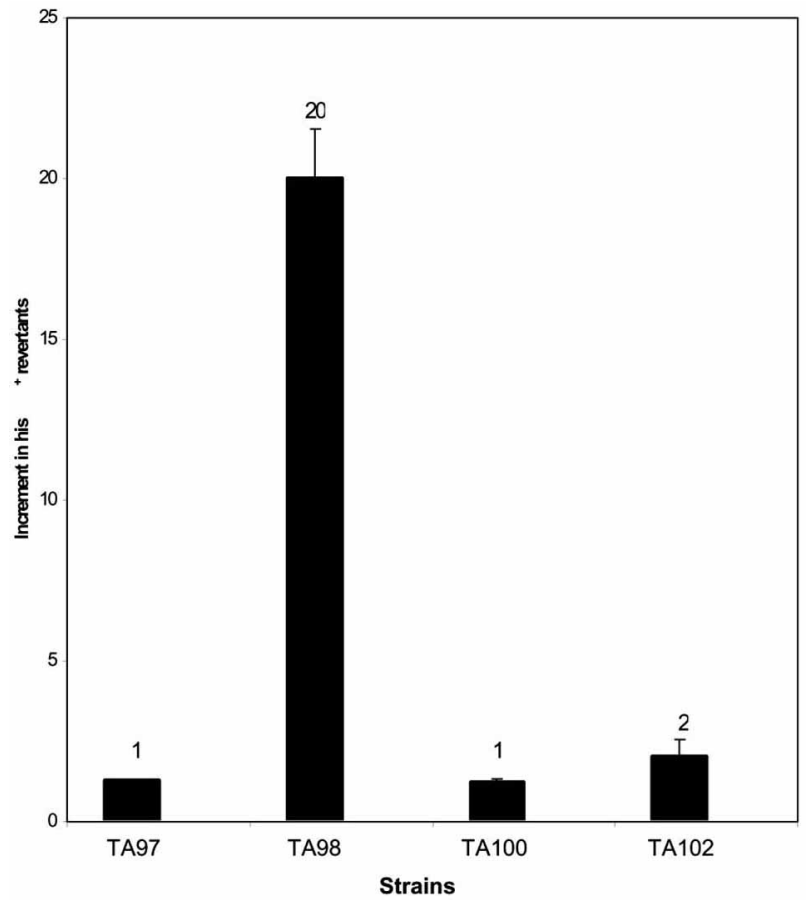

Fig. (5). Mutagenic activity of lyophilized extracts of erva cidreira. Cultures of S. typhimurium in stationary phase of growth were aliquoted into samples of $0.1 \mathrm{ml}$. These samples were pre-incubated (or not, controls) at $37^{\circ} \mathrm{C}$ for $20 \mathrm{~min}$ with $150 \mathrm{mg} / \mathrm{plate}$ of lyophilized extract. After pre-incubation, the samples were poured into E medium plates with $2 \mathrm{ml}$ of molten top agar supplemented with his-bio solution (200 $\mu$ l). Error bars, whenever not apparent, were masked by the symbols.

\section{Study of the Influence of DNA Repair Mechanisms on the Induced Mutagenesis}

The SOS mechanism mediates the mutagenic bypass of replication-blocking DNA lesions caused by many genotoxic agents by DNA polymerase $\mathrm{V}(u m u D C)$ (Woodgate Mol Microbiol 1992) [16]. Erva cidreira extract was able to cause a 15 -fold increase of $t r p^{+}$revertants in the $u m u \mathrm{DC}$ deficient IC204 strain, suggesting that part of the observed mutations are SOS-independent (Fig. 6).

Mutagenesis attributed to the appearance of oxidatively damaged form of guanine, 8-oxo-deoxyguanine (8-oxo-dG), seems to arise from direct bypass by normal replicative DNA 
Table 3. Chromatographic HPLC-DAD UV Analysis of the Total Aqueous Extract

\begin{tabular}{|c|c|c|}
\hline Retention Time (min) & UV Maxima (nm) & Putative Compounds \\
\hline \hline 25.21 & 325 & caffeic acid derivative \\
\hline 27.09 & 331 & caffeic acid derivative \\
\hline 32.36 & $204,261,352$ & flavonol derivative \\
\hline 35.19 & $202,267,337$ & flavone derivative \\
\hline
\end{tabular}

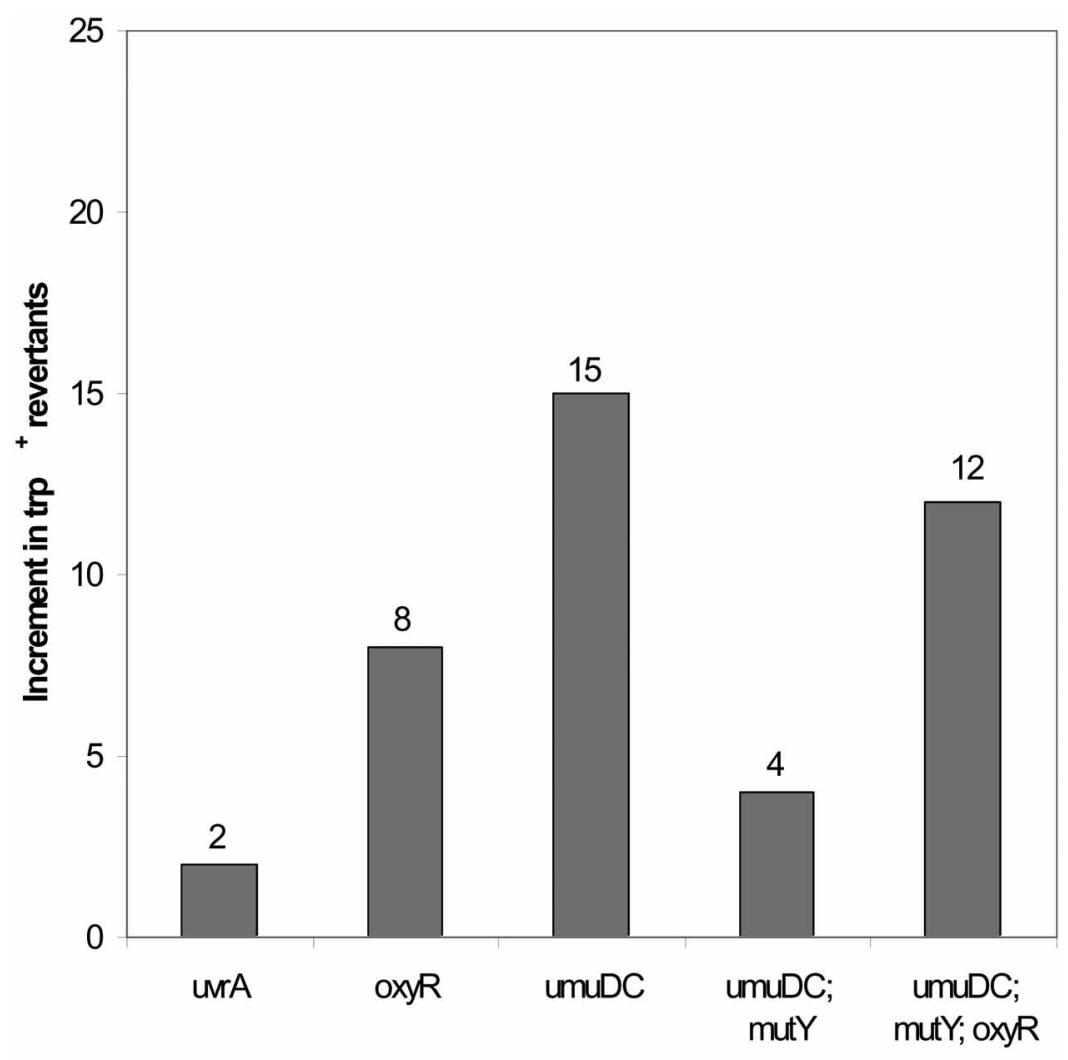

Strains

Fig. (6). Mutagenic activity of lyophilized extract of erva cidreira. Cultures of $E$. coli in stationary phase of growth were split into $0.1 \mathrm{ml}$ samples. These samples were pre-incubated (or not, controls) at $37^{\circ} \mathrm{C}$ for $20 \mathrm{~min}$ with $150 \mathrm{mg} /$ plate lyophilized extract. After pre-incubation, the samples were poured onto E medium plates containing tryptophan $(0.5 \mathrm{mg} / \mathrm{liter})$ added of $2.5 \mathrm{ml}$ molten top agar. Error bars, whenever not apparent, were masked by the symbols.

polymerases (Tchou Mutat Res 1993) [17]. Part of the 8oxo-dG sites may then be found mispaired to adenine. The absence of MutY glycosylase in treated IC206 strain, which detects SOS-independent, 8-oxo-dG-dependent mutations, caused a 4-fold increase in the number of mutants when compared to the spontaneous reversion rate.

Reduced antioxidant defenses in oxyR-deficient strains rendered both IC203 and IC208 strains more susceptible to the mutagenic effects of the erva cidreira extract. The number of revertants in those strains was increased by factors of 8- and 12-fold, respectively, related to their spontaneous reversion rates. Collectively, these results support the idea of a pro-oxidant effect caused by the extract, detectable in DNA repair-deficient backgrounds. Worth to point out that no increment in spontaneous reversion rates were observed in their treated isogenic wild-type strain (data not shown).

\section{Definition of the DNA Hotspot Bases by the Lactose Mutagenesis Assay}

To further evaluate which bases could be targeted in DNA by the action of the erva cidreira extract, additional assays were performed using $E$. coli strains with specific lacZ reversion hot spots (Figs. 7a and 7b). Results presented in Fig. (7a). indicate that erva cidreira extract led to a significant increase in the number of $\mathrm{LacZ}^{+}$revertants in both CC105 (203 revertants) and CC104 (278 revertants) strains. A to $\mathrm{C}$ and $\mathrm{G}$ to $\mathrm{C}$ transversion- (Fig. 7a) and frameshiftderived revertants were also remarkable in the obtained mutation spectrum induced by the extract (Fig. 7b). 

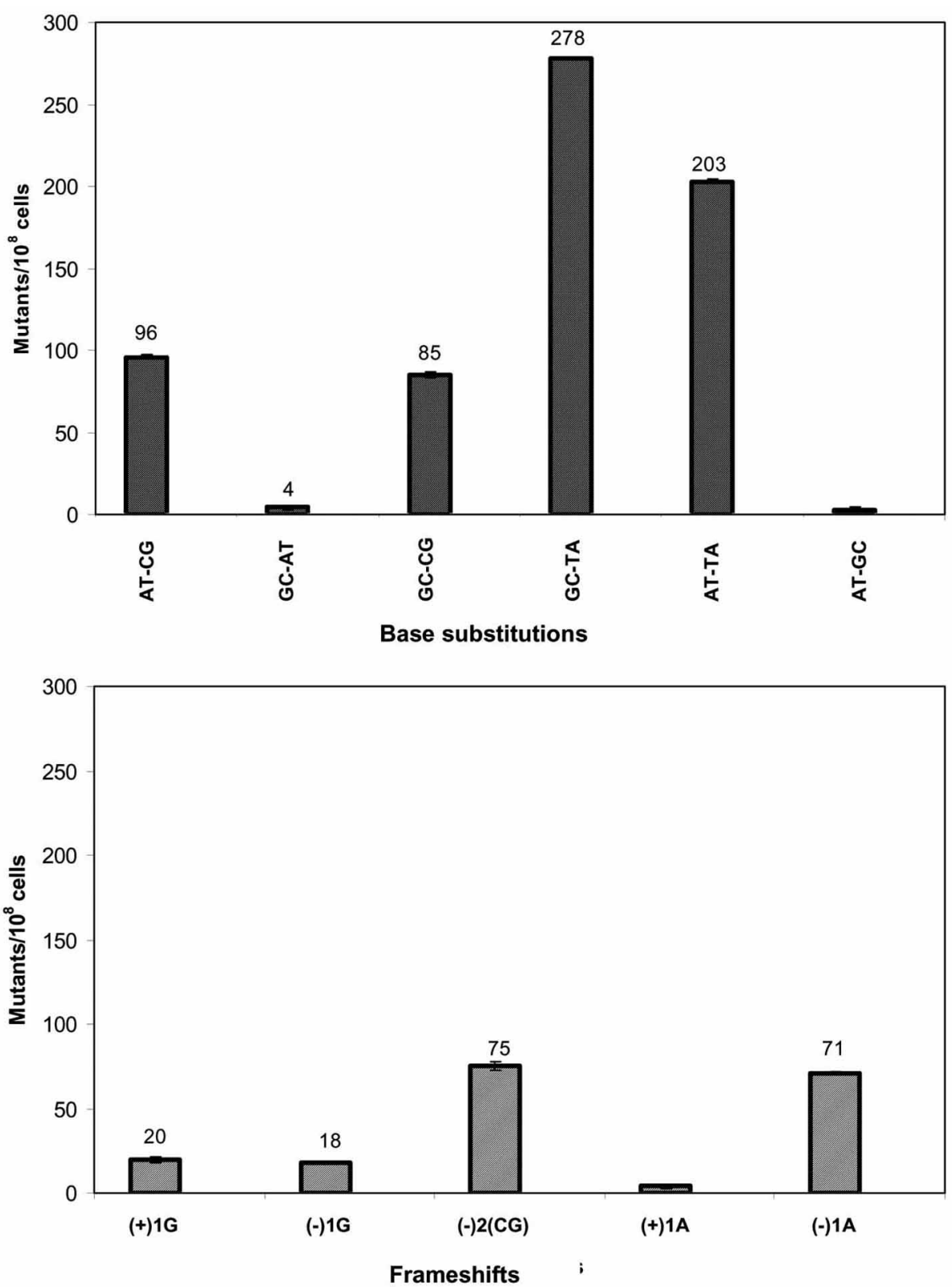

Fig. (7). Mutagenic activity of lyophilized extract of erva cidreira. Cultures of E. coli in exponential phase of growth were pre-incubated (or not, controls) at $37^{\circ} \mathrm{C}$ for $20 \mathrm{~min}$ with $150 \mathrm{mg} /$ plate lyophilized extract each. After pre-incubation, samples of $200 \mu 1 \mathrm{were}$ added to $2 \mathrm{ml} \mathrm{LB}$ medium and incubated overnight. Then, aliquots were poured into minimal medium plates containing $0.4 \%$ lactose. (a) - base substitutions; (b) frameshifts. Error bars, whenever not apparent, were masked by the symbols.

\section{HPLC-DAD Analysis of the Compounds of the Total Aqueous Extract}

Main peaks detected in the chromatographic profile of Melissa officinalis aqueous extract (Fig. 8). by an ultraviolet diode array detector, are typical of phenolic compounds. At retention times of $25.21 \mathrm{~min}$, with UV absorption maximum at $325 \mathrm{~nm}$, and a major one at 27.09 min with absorption at $331 \mathrm{~nm}$, both representatives of a typical profile of caffeic acid derivatives. A relative estimate made from the area under this last major peak accounts for $31.094 \%$ of this derivative in the sample (data not shown). At $32.36 \mathrm{~min}$ (UV absorption peaks at 204, 261, and $352 \mathrm{~nm}$ ) it can be noted the presence of a flavonol derivative, and at 35.19 min (with UV peaks at 202, 267, and 337nm) another one characteristic of a flavone derivative. These classes of phenolic compounds have already been described to occur in Melissa officinalis total extracts. Kurkin et al. (Chem Natural Compounds 1995) [18] isolated and identified rosmarinic acid, ethyl rosmarinate and caffeic acid as phenylpropanoid derivatives and luteolin and apigenin glycosides as flavone derivatives. However, no flavonol derivative had been so far described for Melissa officinalis aqueous extract (see summary in Table 3).

\section{DISCUSSION}

Medicinal plants are amongst the most attractive sources of new drugs (Borrelli Phytotherapy Res 2000) [19]. In Bra- 


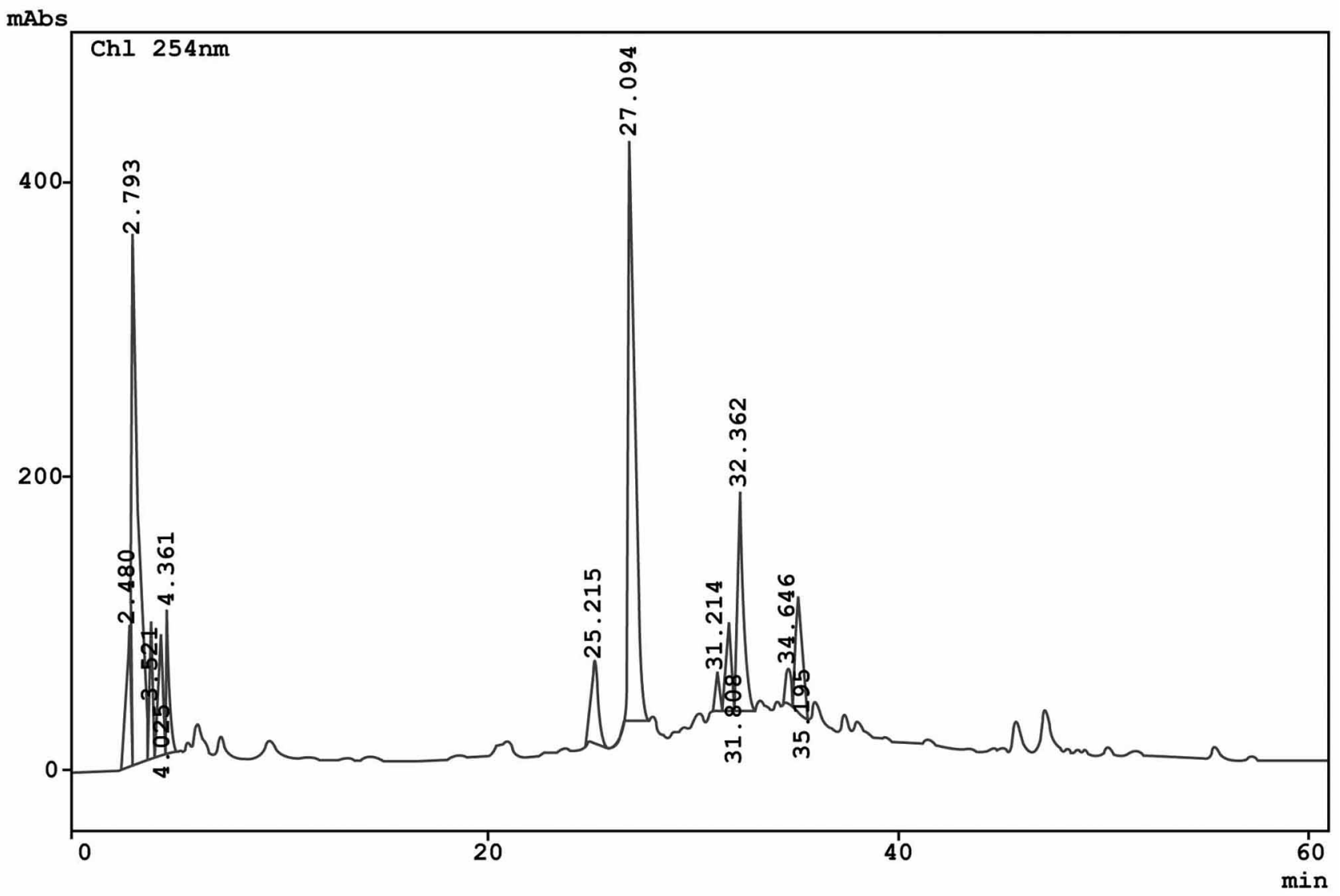

Fig. (8). HPLC-DAD analysis of the total aqueous erva cidreira extract. Selected peaks from the chromatogram were UV scanned and their absorption maxima are given in Table $\mathbf{3}$.

zil, many medicinal plant preparations are used in folk medicine to treat various types of diseases and erva cidreira extracts (M. officinalis) are extensively used without any control. Importantly, although many of its major chemical compounds have already been to described to occur in pharmaceutical preparations, there are no data regarding the evaluation of its possible genotoxic effects.

The current study provides evidence that erva cidreira extract presents genotoxic and mutagenic activities probably due to the presence of phenolic compounds. It was able to induce the $\lambda$ prophage in $E$. coli WP2s $(\lambda)$ strain, and to induce the expression of $\beta$-galactosidase in E. coli PQ37 strain. The mutagenic effect observed in Salmonella typhimurium strain treated with erva cidreira indicates that it may contain substances that generate mutations in GC sites. The spectrum of induced mutations by the extract reveals a strong trend for base substitutions, mainly at guanine and adenine sites in Escherichia coli.

In living cells, the presence of respiratory oxygen renders ROS as important agents of damage by the cellular metabolism. Peroxides present in plant extracts may add extra lethal and mutagenic effects to those derived from the endogenously born ROS. Accordingly, previous studies have reported decreased genotoxicity of tea, mate, guaraná and coffee by addition of catalase, suggesting the participation of ROS in the observed effects (Fonseca J Environ Pathol Toxicol Oncol 2000) [20] (Fonseca Mutat Res 1994) [21] (Leitão
(Leitão Braz J Med Biol Res 1994) [22]. Our present results indicate that such active species could also be involved in the damaging action of erva cidreira extract, as seen by the effective reduction in the observed genotoxic effects adding as many as $10 \mathrm{U} /$ plate catalase.

In the present study, it was also shown that thiourea suppressed the genotoxic effects of erva cidreira extract, suggesting that ${ }^{\circ} \mathrm{OH}$ radicals may take part in these effects. ${ }^{\circ} \mathrm{OH}$ can also appear after reaction of transition metals with reducing agents like $\mathrm{H}_{2} \mathrm{O}_{2}$ in the Fenton reaction, as previously suggested (Koppenol Redox Rep 2001) [23]. In support of this, the observed diminished effects after addition of the $\mathrm{Fe}^{++}$chelating agent dipyridyl strongly suggests that peroxides present in the extract may be able to exert their prooxidant action through ${ }^{\bullet} \mathrm{OH}$ generation.

Analysis of mutagenesis induced by tea and coffee had already been done using S. typhimurium and E.coli test strains (Maron Mutat Res 1983) [11] (Nagao Mutat Res 1979) [24] (Kosugi Mutat Res 1983) [25] (Fujita Mutat Res 1985) [26] (Alejandre-Durán Mutat Res 1987) [27] (Dorato Environ Mutag 1987) [28] (Shane Environ Mol Mutag 1988) [29]. Mutations were shown to arise from both base-pair substitutions or frameshift mutations caused by addition or loss of single or some base pairs.

According to Gatehouse et al. (Mutat Res 1994) [30], the most widely accepted criterion adopted to consider a substance as a mutagenic one is its ability to double the number 
of spontaneous revertants in the Ames test. Erva cidreira extract can thus be considered a mutagenic agent and we have shown that these mutations are targeted to GC sites in the his D locus of $S$. typhimurium TA98.

Besides the Ames Salmonella assay, mutagenic effects of the erva cidreira extract were stressed by other bacterial assays. The first one consists in quantifying revertants to tryptophan prototrophy in treated $E$. coli WP2s strains to screen for the mutagenic activity of the extract. Revertants were shown to increase in the peroxide-sensitive IC203 $(\operatorname{oxy} \mathrm{R})$ strain after treatment with lyophilized extract. An increase in the number of revertants in IC204 strain $(\Delta u m u \mathrm{DC})$, deficient in SOS mutagenic damage bypass, was also observed. It is thus suggested that erva cidreira extract induces oxidative damages in DNA, and part of them can be processed by error-prone repair system, in an SOSindependent manner (Goerlich J Bacteriol 1989) [31]. The triple $u m u \mathrm{DC}$, oxy R and $m u t \mathrm{Y}$ deficiency in IC208 strain did not cause reversion to exceed that observed for the single $u m u$ DC-deficient strain. Survival was reduced to up to $10 \%$ only in IC203 and IC208 strains after treatment, what reinforces a pro-oxidant action of the extract in view of the sensitivity of these strains to oxidative agents (data not shown). Altogether these results forwarded the study to a deeper analysis of the mutagenic spectrum induced by treatment with the extract, since the observed SOS-independent mutagenesis might arise from direct bypass of miscoding lesions such as 8-oxo-dG.

One of the main oxidative damages, induced by both endogenous and exogenous sources, is 8-oxo-dG. This damage is not connected with cellular lethality, instead, with mutagenic activity. Main base substitutions arising from the presence of 8 -oxo-dG comprise $\mathrm{G}: \mathrm{C} \rightarrow \mathrm{T}: \mathrm{A}$ transversions. Significant levels of such transversions are attained whenever one of three specific enzymes involved in its prevention and repair is absent in E. coli: MutT, MutM (Fpg) and MutY proteins.

The mutagenic activity caused by the extract seems to target guanine bases, since the results of Ames test detected frameshift mutations in GC sites. This is also supported by the increase of revertants in IC203 and IC208 strains, both deficient in OxyR function.

To address the mutational specificity of erva cidreira extract in a more direct approach, a set of $E$. coli strains carrying particular point mutations in the lacZ gene (coding for $\beta$-galactosidase enzyme) were used in the lactose reversion mutation assay (Josephy Mutat Res 2000) [32]. Our results show that erva cidreira extract was able to promote $\mathrm{G}: \mathrm{C} \rightarrow \mathrm{T}: \mathrm{A}$ and $\mathrm{A}: \mathrm{T} \rightarrow \mathrm{T}: \mathrm{A}$ as major reversion events, and half-amount of $\mathrm{A}: \mathrm{T} \rightarrow \mathrm{C}: \mathrm{G}$ and $\mathrm{G}: \mathrm{C} \rightarrow \mathrm{C}: \mathrm{G}$ transversions as well. The mutation spectrum generated by the extract resembles, in many aspects, the one induced by ROS (DecuyperDebergh EMBO J 1987) [33] (McBride Biochemistry 1991) [34] (McBride PNAS 1992) [35] (Retel Mutat Res 1993) [36] (Akasaka Mol Gen Genet 1994) [37].

In many cases, guanine sites are the most frequent ones to turn into abasic sites, what could account for the $\mathrm{G} \rightarrow \mathrm{C}$ transversions. $\mathrm{G} \rightarrow \mathrm{C}$ transversions are also quite frequent in the mutation spectrum induced by ROS, however, the mechanism responsible for their appearance it is not known. At first, $\mathrm{G} \rightarrow \mathrm{C}$ transversions could result from the mispairing of 8-oxo-dG with guanines, since 8-oxo-dG could assume the 6-enolate-8-keto anti conformation, and pair up with guanines (Culp Chem Res Toxicol 1989) [38]. However, 8oxo-dG is preferentially found in the tautomeric form 6,8 keto in vitro, and in its syn conformation pairs up with adenines leading to $\mathrm{G} \rightarrow \mathrm{T}$ transversions (Culp Chem Res Toxicol 1989) [38] (Wood Biochemistry 1990) [39] (Cheng J Biol Chem 1992) [40].

In this work, $\mathrm{A}: \mathrm{T} \rightarrow \mathrm{T}: \mathrm{A}$ transversions were also observed after treatment with erva cidreira extract. Similar results were obtained by Grzesiuk and Janion (Mutat Res 1993) [41] studying mutS strains (mismatch repair deficient strains) treated with EMS. These authors observed that strains deficient in the mut $\mathrm{S} u m u \mathrm{C}$ or $m u t \mathrm{~S} u m u \mathrm{D}$ genes were more susceptible to $\mathrm{A}: \mathrm{T} \rightarrow \mathrm{T}: \mathrm{A}$ transversions. Foster and Eisentadt $(\mathrm{J}$ Bacteriol 1985) [42] observed that $\mathrm{A}: \mathrm{T} \rightarrow \mathrm{T}: \mathrm{A}$ transversions are SOS-dependent and occur after treatment of alkA strains with MNNG. The authors considered that these transversions resulted from apurinic sites due to constitutive activity of the other 3-methyl-adenine DNA glicosilase (Tag). Translesion synthesis past abasic sites is highly dependent on the SOS functions (Schaaper PNAS 1981) [43]. In general, when SOS functions are induced, according to the "A rule", adenine is the nucleotide that is preferentially incorporated opposite to abasic sites during bacterial DNA repair (Tessman Cold Spring Harbor Press 1976) [44] (Strauss BioEssays 1991) [45]. The appearance of $\mathrm{A}: \mathrm{T} \rightarrow \mathrm{T}: \mathrm{A}$ transversions is consistent with this adenine insertion during the translesion synthesis as shown for sites derived from depurination induced by chloroethylene oxide I (CEO) (Kunkel PNAS 1984) [46]. Barbin et al. (Mutat Res 1985) [47] observed that this agent produced $\mathrm{A}: \mathrm{T} \rightarrow \mathrm{T}: \mathrm{A}$ transversions in $\mathrm{CEO}$-treated bacteria, and this could result in indirect SOS induction allowing DNA polymerase bypassing a corresponding apurinic site.

In a minor scale, $A: T \rightarrow C: G$ transversions were observed after treatment with erva cidreira extract. These transversions were observed in bacterial strains deleted in mut $\mathrm{T}$ gene, with a 1000-fold increase in the frequency of $\mathrm{A}: \mathrm{T} \rightarrow \mathrm{C}: \mathrm{G}$ transversions related to the wild type strain (Treffers PNAS 1954) [48] (Yanofsky Cold Spring Harbor Symp Quant Biol 1966) [49]. The incorporation of 8-oxo-dGTP in DNA would lead to $\mathrm{A}: \mathrm{T} \rightarrow \mathrm{C}: \mathrm{G}$ base substitutions, as raised by Tajiri et al. (Mutat Res 1995) [50], who postulated that MutT protein could prevent mismatch errors from 8-oxo$\mathrm{dG}$ :A mispairing with adenines in the template strand during replication. Later on, the activity of MutT was shown to be the dephosphorylation of 8-oxo-dGTP from the available nucleotide pool (Akiyama PNAS 1989) [51].

Results presented in this work demonstrate the presence of oxidative compounds in erva cidreira extract. Importantly, it was the popularly used aqueous fraction of ervacidreira the one implicated with the greater genotoxic activity in the present study. Considering a maximum $150 \mathrm{mg}$ amount of extract on $25-30 \mathrm{ml}$ volume of plating medium, hence an average $5-6 \mathrm{mg} / \mathrm{ml}$ of the lyophilized material yielded the observed results. Through HPLC analysis, we found that the genotoxicity of erva cidreira extract is probably due to the presence of phenolic compounds, being ben- 
zoic acid and caffeic acid derivatives supposed the main present chemical species. Caffeic acid (3,4-dihydroxycinnamic acid), one of the most common phenolic acids, is frequently found in fruits, grains (Alberts Garland Publishing 1994) [52] and dietary supplements (Yamasaki Biol Pharm Bull 1998) [4] for human consumption, as simple esters with quinic acid or saccharides, and are also found in traditional Chinese herbs (Perry J Pharmacol 1999) [5]. Although behaved as a non-mutagenic compound when tested against the Ames strains in a previous report (Fung Mutat Res 1988) [53], pure caffeic acid was tested positive for carcinogenicity and was found to induce renal-cell adenomas and a high incidence of renal tubular-cell hyperplasia in mice. In rats, squamous-cell papillomas and forestomach carcinomas and a few renal-cell adenomas were found as result of oral administration of caffeic acid (Hirose Jpn J Cancer Res 1990) [54]. On the opposite, pure rosmarinic acid administered at $2-4 \mathrm{mg} / \mathrm{kg}$ to test mice was shown to be antianxiolytic without any detectable genotoxicity by Comet Assay (Pereira Pharmacol Res 2005) [55]. If the present results on bacterial mutagenesis cannot be attributted to caffeic acid derivatives, it means that other harmful compounds may be somehow found in the total extract made from local plant material. It thus should be taken into consideration that cummulative effects may result from its uncontrolled consume.

As a future perspective, it would also be important to define if both the genotoxins and active principles remain in the same fraction or not. Such pharmacologic approach would then indicate the most proper one for popular use, as it was done for Gingko biloba (Bastianetto J Neurochem 2000) [56].

To conclude, our results indicate that erva cidreira extract has genotoxic and mutagenic substances, and, therefore may be potentially carcinogenic. Further investigations are necessary to define the conditions for its proper medical use without hazard to human health.

\section{ACKNOWLEDGEMENT}

We thank J. S. Cardoso and A. B. Silva for their expert technical support. This work was supported by CNPq, CAPES and FAPERJ.

\section{CONFLICT OF INTEREST STATEMENT}

The authors declare that there are no conflicts of interest.

\section{REFERENCES}

[1] Dimitrova Z, Dimov B, Manolova N, Pancheva S, Ilieva D, Shishkov S. Antiherpes effect of Melissa officinalis L. extracts. Acta Microbiol Bulg 1993; 29: 65-72.

[2] Koytchev R, Alken RG, Dundarov S. Balm mint extract (Lo-701) for topical treatment of recurring herpes labialis. Phytomedicine 1999; 6: 225-30.

[3] Mikus J, Harkenthal M, Steverding D, Reichling J. In vitro effect of essential oils and isolated mono and sesquiterpenes on Leishmania major and Trypanosoma bruci. Planta Med 2000; 66(4): 366-8.

[4] Yamasaki K, Nakano M, Kawahata T, et al. Anti-HIV activity of herbs of Labiatae. Biol Pharm Bull 1998; 21: 829-33.

[5] Perry EK, Pickering AT, Wang WW, Houghton PJ, Perry NS. Medicinal plants and Alzheimer's disease: from ethnobotany to phytotherapy. J Pharmacol 1999; 51: 527-34.
[6] Sugimura T, Sato S. Mutagens-carcinogens in foods. Cancer Res 1983; 43(Suppl): 2415s-21s.

[7] Moreau P, Bailone A, Devoret R. Prophage lambda induction in Escherichia coli K12 envA uvrB: a highly sensitive test for potential carcinogens. Proc Natl Acad Sci USA 1976; 73(10): 3700-4.

[8] Quillardet P, Hofnung M. The SOS chromotest, a colorimetric bacterial assay for genotoxins: procedures. Mutat Res 1985; 147: 65-78.

[9] Miller JH. A short course in bacterial genetics. New York: Cold Spring Harbor Laboratory Press: 1992.

[10] Vogel HJ, Bonner DM. Acetylornithinase of Escherichia coli: partial purification and some properties. J Biol Chem 1956; 218: 97-106.

[11] Maron DM, Ames BN. Revised methods for the Salmonella mutagenicity test. Mutat Res 1983; 113: 173-215.

[12] Blanco M, Urios A, Martínez A. New Escherichia coli WP2 tester strain highly sensitive to reversion by oxidative mutagens. Mutat Res 1998; 413: 95-101.

[13] Cupples CG, Miller JH. A set of lacZ mutations in Escherichia coli that allow rapid detection of each of the six base substitutions. Proc Natl Acad Sci USA 1989; 86: 5345-9.

[14] Cupples CG, Cabrera M, Cruz C, Miller JH. A set of lacZ mutations in Escherichia coli that allow rapid detection of specific frameshift mutations. Genetics 1990; 125(2): 275-80.

[15] Ames BN. Food constituents as a source of mutagens, carcinogens and anticarcinogens. Prog Clin Biol Res 1986; 206: 3-32.

[16] Woodgate R, Sedgwick SG. Mutagenesis induced by bacterial UmuDC proteins and their plasmid homologues. Mol Microbiol 1992; 6: 2213-8.

[17] Tchou T, Grollman AP. Repair of DNA containing the oxidatively damaged base, 8-oxoguanine. Mutat Res 1993; 299: 277-87.

[18] Kurkin VA, Kurkina TV, Zapesochnaya GG, et al. Chemical investigation of the herbage of Melissa officinalis. Chem Nat Compd 1995; 31(2): 266-7.

[19] Borrelli F, Izzo AA. The plant kingdom as a source of anti-ulcer remedies. Phytother Res 2000; 14: 581-91.

[20] Fonseca CAS, Otto SS, Paumgartten FJR, Leitão AC. Nontoxic mutagenic, and clastogenic activities of mate-chimarrão (Ilex paraguariesis). J Environ Pathol Toxicol Oncol 2000; 19: 333-46.

[21] Fonseca CAS, Leal J, Costa SS, Leitão AC. Genotoxic and mutagenic effects of guarana (Paullinia cupana) in prokaryotic organisms. Mutat Res 1994; 321: 165-73.

[22] Leitão AC, Braga RS. Mutagenic and genotoxic effects of mate (Ilex paraguariensis) in prokaryotic organisms. Braz J Med Biol Res 1994; 27: 1517-25.

[23] Koppenol WH. The Haber-Weiss cycle - 70 years later. Redox Rep 2001; 6(4): 229-34.

[24] Nagao M, Takahashi Y, Yamanaka H, Sugimura T. Mutagens in coffee and tea. Mutat Res 1979; 68: 101-6.

[25] Kosugi A, Nagao M, Suwa Y, Wakabayashi K, Sugimura T. Roasting coffee beans produces compounds that induce prophage lambda in E. coli and are mutagenic in E. coli and S. typhimurium. Mutat Res 1983; 116(3-4): 179-84.

[26] Fujita Y, Wakabayashi K, Nagao M, Sugimura T. Implication of hydrogen peroxide in the mutagenicity of coffee. Mutat Res 1985; 144: 227-30.

[27] Alejandre-Durán E, Alonso-Moraga A, Pueyo C. Implications of active oxygen species in the direct-acting mutagenicity of tea. Mutat Res 1987; 188: 251-7.

[28] Dorato G, Barlanchom M, Pueyo C. Coffee is highly mutagenic in the L-arabinose resistance test in Salmonella typhimurium. Environ Mutag 1987; 9: 251-60.

[29] Shane BS, Troxclair AM, McMillin DJ, Henry CB. Comparative mutagenicity of nine brands of coffee to Salmonella typhimurium TA100, TA102 and TA104. Environ Mol Mutag 1988; 11: 195206.

[30] Gatehouse D, Haworth S, Cebula T, et al. Recommendations for the performance of bacterial mutation assays. Mutat Res 1994; 312: 217-33.

[31] Goerlich O, Quillardet P, Hofnung M. Induction of the SOS response by hydrogen peroxide in various Escherichia coli mutants with altered protection against oxidative DNA damage. J Bacteriol 1989; 171(11): 6141-7.

[32] Josephy PD. The Escherichia coli lacZ reversion mutagenicity assay. Mutat Res 2000; 455: 71-80. 
[33] Decuyper-Debergh D, Piette J, van de Vorst A. Singlet oxygeninduced mutations in M13 lacZ phage DNA. EMBO J 1987; 6: 3155-61.

[34] McBride TJ, Preston BD, Loeb LA. Mutagenic spectrum resulting from DNA damage by oxygen radicals. Biochemistry 1991; 30: 207-13.

[35] McBride TJ, Schneider JE, Floyd RA, Loeb LA. Mutations induced by methylene blue plus light in single-stranded M13mp2. Proc Natl Acad Sci USA 1992; 89: 6866-70.

[36] Retel J, Hoebee B, Braun JEF, et al. Mutational specificity of oxidative DNA damage. Mutat Res 1993; 299: 165-82.

[37] Akasaka S, Yamamoto K. Hydrogen peroxide induces G:A to T:A and G:C to C:G transversions in the supF gene of E. coli. Mol Gen Genet 1994; 243: 500-5.

[38] Culp SJ, Cho GP, Kadlubar FF, Evans FE. Structural and conformational analyses of 8-hydroxy-2'-deoxyguanosine. Chem Res Toxicol 1989; 2: 416-22.

[39] Wood ML, Dizdaroglu M, Gajeweski E, Essigmann JM. Mechanistic studies of radiation and oxidative mutagenesis: genetic effects of a single 8-hydroxyguanine (7-hydro-8-oxoguanine) residue inserted at a unique site in a viral genome. Biochemistry 1990;29: 7024-32.

[40] Cheng KC, Cahill DS, Kasai H, Nishimura S, Loeb LA. 8hydroxyguanine, an abundant form of oxidative DNA damage, causes G:C and A:C substitutions. J Biol Chem 1992; 267: 166-72.

[41] Grzesiuk E, Janion C. Some aspects of EMS-induced mutagenesis in Escherichia coli. Mutat Res 1993; 297: 313-21.

[42] Foster PL, Eisenstadt E. Induction of transversion mutations in Escherichia coli by N-methyl-N-nitro-nitrosoguanidine is SOS dependent. J Bacteriol 1985; 163: 213-20.

[43] Schaaper RM, Loeb LA. Depurination causes mutations in SOSinduced cells. Proc Natl Acad Sci USA 1981; 79: 1773-7.

[44] Tessman I. A mechanism of UV reactivation. Abstracts of bacteriophage meetings. In: Bukhari A, Ljungquist E, Eds. Cold Spring Harbor: New York 1976; p. 87.

[45] Strauss BS. The "A" rule of mutagen specificity: a consequence of DNA polymerase bypass of non-instructional lesions? BioEssays 1991; 13: 79-84.
[46] Kunkel TA. Mutational specificity of depurination. Proc Natl Acad Sci USA 1984; 81: 1494-8.

[47] Barbin A, Besson F, Perrard MH, et al. Induction of specific basepair substitutions in $E$. coli trpA mutants by chloroethylene oxide, a carcinogenic vynil chloride metabolite. Mutat Res 1985; 152: 14756.

[48] Treffers HP, Spinelli V, Belser NO. A factor (or mutator gene) influencing mutation rates in Escherichia coli. Proc Natl Acad Sci USA 1954; 40: 1064-71.

[49] Yanofsky C, Ito J, Horn V. Amino acid replacements and the genetic code. Cold Spring Harb Symp Quant Biol 1966; 31: 151-62.

[50] Tajiri T, Maki H, Sekiguchi M. Functional cooperation of MutT, MutM and MutY proteins in preventing mutations caused by spontaneous oxidation of guanine nucleotide in Escherichia coli. Mutat Res 1995; 336: 257-67.

[51] Akiyama M, Maki H, Sekiguchi M, Horiuchi T. A specific role of MutT protein to prevent dG:dA mispairing in DNA replication. Proc Natl Acad Sci USA 1989; 86: 3949-52.

[52] Alberts A, Bray D, Lewis J, Raff M, Roberts K, Watson JD. Molecular biology of the cell. $3^{\text {rd }}$ ed. New York \& London Garland Publishing: 1994.

[53] Fung VA, Cameron TP, Hughes TJ, Kirby PE, Dunkel VC. Mutagenic activity of some coffee flavor ingredients. Mutat Res 1988; 204(2): 219-28.

[54] Hirose M, Fukushima S, Shirai T, et al. Stomach carcinogenicity of caffeic acid, sesamol and catechol in rats and mice. Jpn J Cancer Res 1990; 81(3): 207-12.

[55] Pereira P, Tysca D, Oliveira P, da Silva Brum LF, Picada JN, Ardenghi P. Neurobehavioral and genotoxic aspects of rosmarinic acid. Pharmacol Res 2005; 52(3): 199-203.

[56] Bastianetto S, Zheng WH, Quirion R. The Ginkgo biloba extract (Egb 761) protects and rescues hippocampal cells against nitric oxide-induced toxicity: Involvement of its flavonoid constituents and protein kinase. J Neurochem 2000; 74: 2268-77. 